OLGA LAVRENOVA

Instytut Informacji w Dziedzinie Nauk Społecznych

Rosyjskiej Akademii Nauk

e-mail: olgalavr@mail.ru

\title{
«Ключ Свода». Цитадель А. Экзюпери и Напутствие Вождю о духовном водительстве и идеальном государстве
}

\author{
Abstract \\ "The Keystone". "The Wisdom of the Sands" (Citadelle) by Antoine de Saint- \\ -Exupery and "Suggestions to Leaders" Narrate about Spiritual Guidance \\ and Ideal State
}

The state as a Citadel of the spirit, led by a wise Ruler, is an idea that seems utopian after all the cruel social experiments of the $20^{\text {th }}$ century. But the course of world history is not created in the offices of modern politicians. The milestones of the coming evolution are formed by the thought which is consonant with the divine Beauty, this idea is dedicated to one of the last works of Antoine de Saint-Exupéry - philosophical story-parable Citadel. The heights of the human spirit, which were the basis of the Citadel, were amazingly accordant with the ideas of the book Parting Words to the Leader, a little earlier created on the Himalayan heights.

Keywords: the story Citadel, Antoine de Saint-Exupéry, the book Parting Words to the Leader, Helena Roerich, ideal state, Ruler, Leader

Ключевые слова: повесть Цитадель, Антуан де Сент-Экзюпери, книга Hanymствие Вождю, Елена Рерих, идеальное государство, Правитель, Вождь

Двадцатое столетие, метавшееся между ужасами тоталитаризма и призрачными плодами бездуховной демократии, возможно, останется одной из самых мрачных и самых трагичных страниц мировой истории (хотя XXI век, несмотря на молодость, уже начал вносить свои записи в анналы мировых трагедий). Людям XX века, помимо пережитых мировых войн, довелось быть свидетелями и участниками грандиозной драмы - неудавшейся попытки воплощения мечты тысячелетий о царстве справедливости и свободы на Земле. Эта мечта вдохновляла и вела многих замечательных мыслителей на протяжении истории человечества, и когда в России судьбоносные события начала XX столетия обернулись трагедией миллионов, казалось, что человечество потеряло ориентиры. 
Уничтожение человеческого в человеке было тесно связано с отрицанием Божественного начала, болезнью безверия, поразившей западную цивилизацию в начале XX века. «Бог умер» - провозгласил Ф. Ницше, и это утверждение стало отправной точкой умирания человеческой души, потерянной и одинокой в утратившем свой сокровенный смысл мире. «Тебе показали, как легко убивать богов, но тебе больше нечем дышать, жить. Любая вещь драгоценна ореолом света, пучком нажитых связей, эти связи мы именуем культурой, они - наш язык» ${ }^{1}$ - говорит Экзюпери устами своего героя. «Злоба неверия заливает Мир. Такая злоба самая лютая, ибо она состязается с сущностью Бытия. Она сама себя раздражает и во лжи умерщвляет все возможности» ${ }^{2}$ - сказано в Напутствии Вождю.

Во время Второй мировой войны, ознаменовавшей столкновение двух тоталитарных режимов, строивших «новое совершенное общество», и официально отказавшихся от религии, была утеряна вера не только в Бога, но и в человека, вера в то, что его жизнь может и должна протекать в обществе, построенном на высоких принципах и идеалах.

XX век ознаменовался расцветом антиутопии, в которой суммировался неудачный опыт столетия. Такие крупные представители этого жанра, как А. Платонов, Е. Замятин, Д. Оруэлл, О. Хаксли, своими произведениями закрепили в сознании масс мысль о пагубной сущности авторитарных государств, образованных под лозунгами гуманистических идеалов. Люди отвернулись от высокой идеи, хотя не она была повинна в неудаче великих социальных экспериментов. «Если человек остается рабом внутренне, то никакая социальная свобода не сможет его изменить. Сама же социальная свобода, не подкрепленная духовно, рано или поздно гибнет, превращаясь в собственный антипод» ${ }^{3}$. Именно отсутствием внутренней, духовной свободы, извращением высоких понятий, и были порождены тирании XX века.

Большинство социальных утопий, в том числе и та, которую пытались реализовать в России, были основаны на идее возможности существования справедливого общества, вытекающей из определенной организации социальных институтов. То, как легко превращаются любые социальные построения в орудие безграничной власти одного человека, наглядно продемонстрировало прошлое столетие...

\section{Мечта}

Как бы в противовес новейшим социальным теориям мировая культура сохранила легенды и мифы о мудром правлении древних Царей-Первосвященников, утверждавших Божественные законы на земле. «Миф же есть не вымысел, а реальность, но реальность иного порядка, чем реальность так

\footnotetext{
А. Сент-Экзюпери, Сочинения в двух томах, том 2: Цитадель, Москва 1994, с. 233.

2 Напутствие Вождю, с. 165.

3 Л.В. Шапошникова, Град Светлый, Москва 1998, с. 87.
} 
называемой объективной исторической действительности» ${ }^{4}-$ писал русский философ Н.А. Бердяев. И человечество интуитивно ощущало высшую справедливость этой иной реальности, относящейся не только к далекому прошлому, но и ко всеобщим законам мироздания. Потому и в безбожном XX веке люди продолжали мечтать о Царстве Духа на земле и о его боговдохновенном Правителе.

Идея о Правителе от Бога не случайно вновь была дана миру именно в тот период истории, когда зарождались и крепли тоталитарные режимы последнего столетия, когда человечество сделало свой выбор в пользу построения бездуховного общества. Именно тогда и были созданы великие произведения, оценить которые по достоинству предстоит грядущим поколениям.

Французский летчик и блистательный писатель-гуманист, автор замечательной и всемирно известной сказки-притчи Маленький Прини, Антуан де Сент-Экзюпери в своем последнем, эпохальном философском произведении Цитадель развернул картину гипотетического Царства, которое можно было бы назвать Царством Духа. По замыслу автора оно неотделимо от личности его Правителя, ведущего свой народ путями Божественного провидения.

Это произведение стало закономерным итогом творческой биографии французского писателя. Все творчество Сент-Экзюпери, начиная с самых ранних его произведений, было направлено на то, чтобы «возродить общегуманистические начала культуры, придающие смысл существования личности, пробуждающие ее стремление к непрестанному самосозиданию, низвергающему оковы омассовления бездушной цивилизации» ${ }^{5}$. Настольной книгой Экзюпери были труды физика и философа Блеза Паскаля, который размышлял о тайнах бытия и трагической хрупкости человека - «мыслящего тростника», находящегося между двумя безднами - бесконечностью и ничтожностью. Его блистательные эссе о «разуме сердца» и философии постижения «внутреннего человека», взаимоувязанного с Господом в неразрывную цепь, волновали писателя-гуманиста, наблюдавшего жестокую реальность XX века и нашли свое отражение в его творчестве.

Десятилетием раньше, чем была написана Цитадель, в начале 1930-х годов, оригинальный русский философ Елена Ивановна Рерих, в творчестве которой нашли отражение духовные традиции Востока и Запада, собрала книгу Напутствие Вождю. Она не вошла в корпус книг учения Живой Эти$\kappa u$, представляющего философскую основу всего творчества семьи Рерихов, но неразрывно связана с ней. И Живая Этика (состоящая из девяти книг, написанных в 1920-1936 гг.), и Напутствие Вождю (1933) ${ }^{6}$ создавались как результат духовного сотрудничества русской женщины с Мудрецами Востока, которых в Индии называют Махатмами - Великими Душами. Это целостная философская система, говорящая о человеке как о неотъемлемой

4 Н.А. Бердяев, Смысл истории, Москва 1990, с. 28.

5 Б. Губман, Маленький прини над ичитаделью духа [в:] А. Сент-Экзюпери, ор. cit., том 2, c. 544 .

6 Книга была издана три года спустя: Hanymствие Вождю, Ryga [1937]. 
части Вселенной, представляет собой одно из лучших произведений русского космизма.

Hanyтствие Вождю - текст, вобравший в себя главнейшие проблемы организации общества - намеренно было издано тиражом в 50 экземпляров и явно не предназначалась для времени, в котором было написано. Вождь здесь предстает как духовный Учитель своего народа, как Водитель-Иерарх, звено в иерархической Цепи, один конец которой находится на Земле, другой - уходит в беспредельные глубины Космоса, к изначальным законам Божественного миропорядка. Одновременно книга указывала те пропасти, в которые, как это и подтвердила история, суждено упасть властителю, сбившемуся с духовного пути.

Оба произведения зародились за пределами западной цивилизации. Цитадель возникла после соприкосновения автора с культурой мусульман-кочевников Северной Африки, и само повествование книги развертывается в североафриканской пустыне. Напутствие Вождю было создано в Индии спустя несколько лет после завершения беспрецедентной Центрально-Азиатской экспедиции (1924-1928) 7 .

Оба произведения имеют сходную структуру - представляют собой казалось бы разрозненные параграфы, которые как по спирали возвращаются к одной и той же мысли через некоторый промежуток времени и развивают ее в новом ключе.

В этих книгах, в солидном фолианте Цитадели и помещающемся в кармане Напутствии Вождю, чрезвычайно много философских параллелей.

Красной нитью через обе книги проходит мысль о необходимости «связи вождя с Высшим, которая ставит вождя в цепь Иерархии и придает его действиям эволюционный характер» ${ }^{8}$. Именно Правителю должна быть присуща духовная свобода - без нее невозможно невозможно и духовное раскрепощение народа.

\section{Социальный строй и личность}

Книги Цитадель и Напутствие Вождю повествуют не о теократии, упорядочивающей жизнь общества законами Священного Писания, не о власти правителя, обожествленного подобно фараонам Древнего Египта, не о самодержце, установленном исполнением формального обряда помазания на царство, но о боговдохновенной власти мудрого человека, имеющего высшее достижение духовного прозрения, свойственное праведникам, под-

7 Центрально-Азиатская экспедиция русского мыслителя, художника и общественного деятеля Н.К. Рериха была организована Музеем Рериха в США и прошла в 1924-1928 годах по труднодоступным регионам Индии, Ладака, Синцзяна, Алтая, Монголии, Китая, Тибета и вернулась в Индию. Исследовались культура и археология этих районов, Н.К. Рерих на всем маршруте писал пейзажи и сюжетные полотна. По результатам экспедиции были изданы дневники участников - Altai-Himalaya (1929) Н.К. Рериха и Trails to Inmost Asia (1931) Ю.Н. Рериха, старшего сына Рерихов, востоковеда.

8 Л.В. Шапошникова, ор. cit., с. 144. 
вижникам и пророкам - духоразумение. Не о властителе, заботящемся об устойчивости задолго до него сложившегося государства и общества, но о Вожде и Правителе, которому под силу сотворить свой народ. О Вожде, воплощающем божественный импульс в социальную материю, подобно тому как скульптор материализует высокое вдохновение в мягкой глине или неподатливом камне.

Сюжетная линия Цитадели устремлена к уже отжившим формам организации общества - Экзюпери писал о просвещенной монархии. Hanymствие Вождю создано в созвучии с так и не воплотившимися на государственном уровне принципами общины, объединяющей духовно свободных людей и способствующей согласованному развитию личности, а не обезличиванию9. Но социальный строй - лишь инструмент в руках главы государства. Как показала история, правитель способен использовать любые социальные институты как во вред своему народу, так и во благо. Действие во благо возможно лишь тогда, когда водитель народов сам ведом Надземной Мудростью. Только если через личность правителя Высшее воплощается в земные формы, государство становится отзвуком надземной справедливости.

Благосостояние народов складывается около одной личности. Примеров тому множество во всей истории, в самых различных областях. Многие отнесут это несомненное явление к личности как таковой. Так поступают близорукие, но более дальновидные понимают, что такие собиратели не что иное, как мощь Иерархии. [...] Но необходимо и другое качество со стороны самого народа - нужны доверие и сознание силы ${ }^{10}$.

Я - зодчий. Душа и сердце. Я прихожу и берусь за окружающий меня материал. Bсе вокруг - глина, и я начинаю трудиться, подчиняя ее творческому замыслу, рожденному во мне Господом, а не логикой. Я творю свое царство, одержимый духом, который воплотится в нем, творю так же, как пишутся стихи, не давая никому отчета, почему переставил запятую, почему заменил слово - дух, открывшийся сердцу, ищет сказаться и ведет ${ }^{11}$.

\section{Между Небом и землей}

Общение с Высшим, с небесной Иерархией, несущей в себе мудрость Божественных законов, поднимает Вождя в иные сферы бытия, позволяя судить о реальности с высот духа. Но и в этом высоком общении Высшая Тайна остается неоткрываема, ибо «Тайною живет мир» ${ }^{12}$.

Самой сокровенной тайной остается Господь для Правителя Цитадели. Прикосновение мира горнего безмолвно снимает все вопросы, поднимая сознание вопрошающего над обыденными проблемами, выводя в иное пространство, в иную систему координат. Правитель являет собой Истину,

9 Об этих принципах повествует более подробно одна из книг созданного Рерихами философского учения Живой Этики - Община.

10 Напутствие Вождю, пролог.

11 А. Сент-Экзюпери, ор. cit., том 2, с. 24.

12 Напутствие Вождю, с. 98. 
открывшуюся ему в безмолвной Беседе, и для своего народа он становится ступенькой в лестнице, ведущей к Господу. Правитель Цитадели, сошедший с горы после безответной беседы с Господом, обнимал сердцем своих собратьев по цивилизации, истерзанных социальными потрясениями и беспросветным безверием:

Я вернулся к моему народу и впервые обнял его молчанием моей любви, понуждая моим молчанием приносить мне дары всю их жизнь. [...] Я знал, что не мне брать у них. Во мне они должны были сбыться, и душа их должна была зазвучать в моем молчании. С моей помощью все мы вместе становились молитвой, которую рождало молчание Господа ${ }^{13}$.

...Сердце Вождя живет подвигом народа. У него нет страха и слова «боюсь»нет в его словаре. Ярко зажигает он своим примером Свет и создает сознание народа ${ }^{14}$.

Правитель есть пример живой. Правитель есть слагатель пути по всем мирам ${ }^{15}$.

О сакральном значении молитвенного молчания говорит и философское учение Живой Этики, с которым неразрывно связано Напутствие Вождю. В молчании, незримо и безгласно, прикасается к человеческой душе весть и указ горнего мира.

...Но, среди достижений, оставь время для молчания духа.

В это время Я коснусь твоей сущности.

Крупица Великого Молчания ведет к познанию Служения ${ }^{16}$.

Божественная весть замыкает уста получившего ее...

...Так же и в учении Духа.

Ученик получает озарения радости.

Получает бездну исканий.

Получает лед одиночества.

И затем должен пройти тягость средоточия.

Как бы один, как бы безгласный,

Как бы без помощи,

Он несет на себе тягость всех.

И так же покойный, как во льду одиночества,

Он ждет и с готовностью принимает тягость обращений.

Как бы основа здания, молчаливо он дает окружить себя.

И удесятеряет руки свои,

И умножает сердце свое,

И должен вырасти духом

На всех обратившихся ${ }^{17}$.

Вождь - ученик, принявший духовное водительство небесной Иерархии, ученик на пути к высшей мудрости, звено в цепи, соединяющей небесное

13 А. Сент-Экзюпери, op. cit., том 2, с. 199.

14 Напутствие Вождю, с. 39.

15 Ibid., c. 181.

16 Листы сада М. Зов. Запись от 14.10.1922.

17 Ibid., запись от 26.08.1922. 
и земное. Также и Правитель Цитадели - звено в этой цепи, ступень в лестнице к Господу.

\section{Вдохновенное творчество}

Принимая высшее вдохновение, Вождь и Правитель несет, тем не менее, единоличную ответственность за то, как этот импульс будет реализован, за выбранный путь, который должен привести народ к Господу. Его ведет устремление в будущее, более совершенное, чем настоящее. Поэтому в $\mathrm{Ha}$ путствии Вождю предпочитается понятие Вождя понятию Правителя, устремление в будущее - неподвижности стабильного миропорядка.

Могут спросить, почему Говорю о Вожде, а не о Правителе? Различие между ними огромное. Правитель предполагает настоящее и как бы управление чем-то уже существующим, но Вождь являет, в самом значении слова, будущее. Он не получил уже сложенного, он ведет, и каждое его действие устремляет вперед. Правитель знает уже сложенное и законченное, но Вождь не имеет утвержденного ранее и должен привести народ к Горе Совершенства. Если тягость Правителя велика, то ответственность Вождя еще больше, но зато и Силы Превышние утверждают Свой Престол там, где есть признаки водительства ${ }^{18}$.

Правитель Цитадели, слагающий пути, также имеет в себе необходимые качества водительства.

Я веду. Я - вождь. Я - мастер. Я отвечаю за созидание. [...] Я и только я - творец картины, собравшей воедино отары и дома, коз и горные кряжи, - картины, в которую мой народ влюбился, словно в юную богиню, раскрывшую ему на заре объятия, картины, которой никто еще и никогда не видел. Моему народу полюбилось царство, созданное произволом моего творчества. Он полюбил его, а значит, полюбил и меня зодчего. В статуе любят не глину, не бронзу, не мрамор, - душу ваятеля. [...]

И если я сумею сделать мое царство таким высоким, что и звезды найдут в нем свое место, то народ мой, встречая ночь на пороге, поднимет глаза к небу и возблагодарит Господа за то, что Он мудро ведет Свои корабли. И если мое царство окажется столь протяженным, что его хватит на всю человеческую жизнь, то народ мой будет идти от праздника к празднику, словно от преддверия к преддверию, зная, что будет за дверями, и различая среди дробности мира лик Господа ${ }^{19}$.

К Вождю и Правителю применимы самые высокие требования. Собирание в себе самых огненных качеств, сочетание внутреннего напряжения и точного действия - удел Вождя, несущий ему возможности непрерывного духовного совершенствования. Так неразрывно связаны построение государства - Цитадели Духа и внутреннего роста, самотворчества и самосовершенствования Вождя, устремленного к небесной Иерархии.

Именно, как сосуд закрытый, как гора неразграбленная, как лук стрелою напряженный, - так стоит Вождь. И что напиток сосуда пламенен, и что гора неистощима, и стрела смертельна - так действует. Ибо кто осмелится утверждать, что трудность

18 Напутствие Вождю, с. 4.

19 А. Сент-Экзюпери, ор. cit., том 2, с. 24-25. 
не есть скорейше достижение! Молочные реки прокиснут, и кисельные берега для сидения неудобны. Итак, в кольчуге личной ответственности поспешает Вождь ${ }^{20}$.

Правитель Цитадели несет свое Царство в сердце, расширяющемся по мере наполнения его божественным смыслом. В помощь Правителю и далекие княжества, благодаря которым он становится пространственней, в помощь и возлюбленный враг, примирение с которым возможно лишь в Господе. Величие того, над чем трудится человек, преображает и перерождает его. «Вы станете великими, если камни, над которыми вам дана власть, перестанут быть просто камнями, предназначенными служить нехитрым будничным удобствам, но станут ступенями, ведущим к престолу Господа» ${ }^{21}$. Так же, как в сердце архитектора рождается Храм, в сердце Правителя рождается его Царство, и судьбы людей служат Царству так же, как камни служат Храму. Храм - сокровенный смысл камней, из которых он сложен, Царство смысл человеческих судеб, становящихся молитвой Господу.

Строя свое государство как Храм, Правитель взыскует Господа. Молитвенно созидая, он не только соединяет в себе земное и небесное, но и выполняет предначертанное. Мудрые предания всех народов повествуют о том, что человек не должен обольщаться, считая, что он самостоятельно ищет Господа, ибо жажду богопознания рождает в человеческом сердце Бог. «...Чтобы вырастить дерево, ты должен бросить в землю семечко. Деревья приходят сверху, а не снизу» ${ }^{22}$. На ощупь, «как слепые гусеницы ощущают солнце» ${ }^{23}$, движется человек Ему навстречу. Направление этого движения задается смутной тоской по неведомому, по тем торжественным истинам, которые еще не имеют для человека смысла, но неодолимо притягивают к себе.

\section{Традиции и уклад}

Внимание и одобрение боговдохновенного Правителя к своим подданным замыкает иерархическую цепь, позволяя солдату или крестьянину ощущать приобщение к чему-то более высокому. Эта иерархическая связь - не массовый психоз безусловного обожания, свойственный тираниям, но «роскошь человеческого общения», доступная Иерарху и ведомым им, она имеет особое значение благодаря укладу - культурному наследию, превращающему обиход в священный текст. Созидаются традиции, которые наполнены глубоким смыслом бытия. Личное внимание Вождя и Правителя-Иерарха к повседневному укладу, к меньшему из сотрудников, творящему вместе с ним Царство Духа, рождает причастность каждого к законам космического миропорядка, которые олицетворяет собой Вождь.

\footnotetext{
20 Напутствие Вождю, с. 46.

21 А. Сент-Экзюпери, op. cit., том 2, с. 80.

Ibid., c. 228.

Ibid., c. 309.
} 
Вот я пришел и сел за стол последнего из своих слуг. [...] И если я расспрашиваю его о пахоте, то не из низкого желания польстить ему и расположить к себе - мне не нужны избиратели - я спрашиваю, потому что хочу поучиться. Когда спрашивают и не выслушивают ответа, ощутимо презрение. И ответивший нащупывает в кармане нож. Но мне важно знать, сколько маслин приносит оливковое дерево, я внимательно выслушиваю ответ. [...] Моя власть безусловна, поступки мои не диктуются низкой корыстью, я способен чувствовать свойственную людям благодарность ${ }^{24}$.

Много глухих, дальних мест должны слышать голос Вождя. Он должен показать, что все созидание ему близко, и каждый стремящийся к улучшению и усовершенствованию найдет в Вожде одобрение и ласку ${ }^{25}$.

Правитель Цитадели увязывает воедино Дух и материю путем традиционного уклада, освященного значимостью Царства. Если Царство создано как Храм для молитвы Господу, малейшая деталь обретает не только сокровенный смысл, но и только ей присущее значение. Создаются связующие нити, соединяющие небесные смыслы и земные вещи. Создается то, что и есть культура в ее высоком понимании - лестница от обыденности к Господу. Не случайно в Цитадели велика роль уклада и иерархии. Задача Правителя - из вещей создать знаки, которые, как слова в священном писании, создают текст, хранящий в себе дыхание благодати и устремляющий читающего далеко за свои пределы. Правитель создает священный текст своего Царства, и любовь становится его неотъемлемым свойством. О Родине, а стало быть, не столько о земле, сколько о национальной культуре, говорится и в Напутствии Вождю, утверждая ее как трамплин к Беспредельности:

Родина утверждает магнитное притяжение к определенному складу духа. [...] Не только земная родина привлекает человека, она лишь как отправная точка для Беспредельности. Можно ли унижать земную родину сопоставлением с Беспредельностью?! Наоборот, каждое возношение будет достойно сердца Вождя ${ }^{26}$.

\section{Метафоры и знаки}

Цитадель и Напутствие Вождю - тексты, проникнутые изысканной поэзией, и в них раз за разом повторяются полные сокровенного смысла метафоры. Правитель, ставший ключом свода Храма-государства; тишина Храма; молчание Господа и Государя, рождающее молитвенное созидание Человека...

Правитель Цитадели строит свое государство-Храм так, чтобы каждая его часть была знаком, несущим суть божественной истины, ибо Храм есть символическое отражение божественного миропорядка.

Метафора здания-государства встречается и в Напутствии Вождю, творческое начало становится критерием правильности его построения, а его основным свойством - соизмеримость и вмещение высшей красоты

\footnotetext{
24 Ibid., c. 170.

25 Напутствие Вождю, с. 125.

26 Ibid., c. 13.
} 
гармонии Мироздания. Это не склад для вещей и абстрактных свобод, в его стенах должна литься песнь и развиваться творчество.

Строитель должен знать, как нагрузить столбы дома. От несоизмеримости происходит разрушение, кощунство, ложь, предательство и все безобразные явления. [...] Условия строительства - полная соизмеримость мысли и выражения - это оплот правды красоты ${ }^{27}$.

Еще одна метафора для отражения сути построения под водительством Господа - государство-Корабль, Вождь и Правитель - Кормчий ${ }^{28}$. В этой метафоре - философия устремления, движения к заветной цели под Высшим Водительством.

К Горе Совершенства ведет свой народ Вождь. В гору ведет свой народ Правитель Цитадели. Молитва Правителя Цитадели и принятие духовного водительства Господа совершается на горе - в ткань книги-притчи органично вписывается один из наиболее значимых архетипов человеческого сознания. Вселенское одиночество поднявшегося на вершину и близость горных вершин к Небу, особые условия высокогорий, предваряемые тяжелым подъемом-испытанием, приуготавливающим душу к восприятию высокой Истины - все это значимо в мировой культуре и несет особый смысл восхождения души к Богу. Перед поднявшимся на вершину открывается иной пейзаж долины, где нет места частностям, зато она становится доступной взгляду целиком. Мысленному взору Правителя должно открываться Целое - его государство. Только в живительной цельности обретают смысл вещи и люди Цитадели.

\section{Государство и человек}

Вождь и Правитель направляют чаяния людей к создаваемому государству, заботятся о том, чтобы это созидание стало для них путем к Небу и смыслом жизни.

Приоритет социального целого над частным, государства над личностью - мысль вроде бы не новая и в европейской историографии нового времени начавшая свой путь с Государя Николо Макиавелли. К сожалению, западная социальная мысль, особенно в XX веке, не склонна была рассматривать нюансы целеполагания таких идей. Если из камней сложить амбар, их смыслом станет обыденность. Если подчинить людей не Царству Духа, а обычной административной машине, то они, служа этой машине, перестанут служить Господу, станут «винтиками» механизма.

В Цитадели и Напутствии Вождю построение государства - не цель, а средство преображения человека. Преображение совершается не запретами и репрессиями, но боговдохновенным творчеством, совместным созида-

27 Ibid., c. 49.

28 Здесь опять следует вспомнить, как легко извращаются высокие понятия, когда в интересах тираний используются древнейшие архетипы. «Великий кормчий» - так называли идеологи коммунизма Иосифа Сталина и Мао Цзедуна. 
нием. И только истинному Вождю и Правителю под силу повести свой народ этой дорогой, не совершить подмену высоких идеалов пустыми лозунгами.

Но вот пришло время тебе встревожиться: ты видишь - жестокий тиран уничтожает людей. Ростовщик держит их в рабстве. Строитель храма служит не Господу, а себе, выжимая себе на потребу из людей пот. И не заметно, чтобы людей это облагородило. $[\ldots]$

Что за смысл в возводимой тобой пирамиде, если не венчает ее Господь? Он преображает людей и открывается преображенным. Ты вправе беззаветно служить князю, если сам он беззаветно служит Господу ${ }^{29}$.

Помните, насколько нужно людям понятие Вождя. Они хотят иметь поручителя перед Высшим, они понимают, насколько не найти пути без связи... ${ }^{30}$

Вождь следит за напряженностью творчества, в каждом социальном построении верно то построение, где окрыляется разнообразное творчество. Если творчеству тягостно, это верный признак ошибки в построении. Этим ошибкам не следует давать гнездиться. Зовите каменщиков, перекладывайте стены, пока песнь не зазвучит свободно ${ }^{31}$.

\section{Красота построения и свобода}

Обе книги повествуют не только о духовном водительстве, но и о противопоставлении власти и произвола, об ответственности Правителя на грани между добром и злом, между Служением великим истинам и себеслужением. Умение Правителя не преступить грань - великое таинство, духовная мистерия преодоления великого искушения - превращается в потенциальную возможность социальной реальности.

Вождь стоит на гребне, у которого нет спуска. Найти границу между противоположениями может Вождь прирожденный. Из этих тайных границ сотканы ковры победы. Каждый день, каждый час перед Вождем расстилается пряжа тайн. Вот перед ним снисходительность или попустительство. Конечно, из первого рождается второе, но между ними лежит Меч Справедливости. Ведь снисходительность от Света, но попустительство - уже от тьмы. На гребне между ними лежит Меч Вождя. Узко место, где может лежать Меч. Также узка грань между мужеством и жестокостью. Лишь сердце Вождя знает, где эти грани ${ }^{32}$.

Красотой построения, широтой поставленных задач и, наконец, устремлением в будущее и к Высшему создается мирное сотрудничество абсолютно разных людей. Создать эту Красоту может лишь Вождь и Правитель, внимающий высшим законам Мироздания.

\footnotetext{
29 А. Сент-Экзюпери, ор. cit., том 2, с. 228.

30 Напутствие Вождю, с. 5.

Ibid., c. 66.

32 Напутствие Вождю, с. 1.
} 
...Вождь должен найти путь новых задач, достаточно широких, чтобы поглотить трение ${ }^{33}$.

- Господи! Они враждуют, потому что не строят больше царства. Я не обманываюсь, думая, что царство не строится больше оттого, что они принялись враждовать. Научи меня, Господи, какой должна быть башня, чтобы они, несмотря на все свои несогласия, захотели потратить себя на нее. Башня, которая нуждалась бы в каждом из них и каждого бы насытила, понудив достигнуть предела своих возможностей и обогатив ощущением величия ${ }^{34}$.

Возникшие в эпоху рождения и развития тоталитарных режимов, эти книги указывали целесообразность адекватного применения власти. Вместо репрессивных методов правления предлагалось своевременное направление энергии масс в оптимальное для духовной эволюции русло. Но принять единственно правильное решение может только Правитель-Иерарх, собеседующий с Господом подобно библейскому Царю Давиду. Лишь такой Правитель и Вождь способен опираться не на принуждение, но на дисциплину духа своих сотрудников и подданных.

Нужно избегать всяких запрещений и заменить их своевременно направленным указом. Лучше звучит, когда Вождь скажет - делайте, творите, нежели - запрещаю. Каждое отрицание уничтожает часть уважения к Вождю, но действительно, Указ может быть жизненным лишь своевременностью. Но кто же, кроме Иерарха, может усмотреть своевременность? Потому жемчужина силы Вождя лишь в общении с Иерар$\mathrm{xoM}^{35}$.

Нужно проявить дисциплину духа, без нее не сумеете стать свободными. Для раба она будет тюрьмою, для свободного она будет садом прекрасно-целебным ${ }^{36}$.

Я не вижу, в чем противоречит принуждение свободе. Чем больше проторил я дорог, тем свободнее ты в выборе. Хотя каждая из дорог - принуждение, потому что я оградил ее дорожными столбами. И что ты имеешь в виду, говоря «свобода» и не видя перед собой ни одной дороги? Или ты называешь свободой блуждание наугад в пустоте? Поверь, принуждение новой дороги увеличит твою свободу ${ }^{37}$.

Но Правитель и Вождь поставлены перед фактом множественности земных истин. По сути, это враждебность разных знаковых систем, каждая из которых жизненна лишь до той поры, пока обладает внутренней целостностью, не смешиваясь с другими. Значимость такой системы в способности служить дорогой к Господу. Лестница в небо складывается из ступенек традиционного уклада, наполненного сокровенными смыслами веками сложенных ритуалов, освященных значимостью Царства. Единственная Истина, которая снимает все противоречия, находится вне уклада, она - в Господе.

\footnotetext{
33 Ibid., c. 67.

34 А. Сент-Экзюпери, ор. cit., том 2, с. 68.

35 Напутствие Вождю, с. 118.

Ibid., c. 42.

37 А. Сент-Экзюпери, ор. cit., том 2, с. 218.
} 
Много земных малых правд нужно покрыть куполом великодушия. Нужно покрыться Светом, идущим от Иерархии... ${ }^{38}$

Я знаю: противостоят друг другу только слова, а человек, поднимаясь ступенька за ступенькой вверх, видит все по-иному, и нет для него никаких противоречий ${ }^{39}$.

Полифония смыслов приводит к необходимости выбора. Правитель Цитадели стоит лицом к лицу с проблемой тонкой грани в жестоком ее варианте. В числе многих притч, из которых состоит Цитадель, есть и такая, в которой заблудшему Правителю, прошедшему через выбор своей истины и через кровь, «Божьей мудростью [...] было даровано поучение о власти» ${ }^{40}$. Суровость Правителя, призванная преображать людей, оправдана только в том случае, если она превращает человека из бесформенной личинки в крылатое существо. «Но что толку в суровости, если, пройдя через ворота и потеряв самого себя вместе с коконом, человек не ощутит за спиной крыльев, а узнает, что он - жалкий калека?» ${ }^{41}$ Тонка грань, которую Правителю нельзя преступить, не обратившись в тирана. Противоречия между крайностями предпочтений снимаются в духе человека, поднимающегося ввысь. А необходимость суровости - безусловной универсальностью языка, на котором можно объяснить человеку высокие истины. «Властвуют не суровостью - доступностью языка. Суровость помогает обучить языку, который ничем не обусловлен извне, который не истинней и не лживей других, но просто говорит об ином» ${ }^{42}$.

Казни и насилие означают несостоятельность Правителя в созидании, его неспособность обратить людей в свою веру из-за ее слабости. Если Правителю по вере его открыт язык Истины, он может обойтись без принуждения в созидании Человека. Цитадель Духа не будет таковой, если в ней есть место человеческому горю. Оно - свидетельство несовершенства построенного Храма-государства. Эта истина открывается Правителю, встретившему на своих путях плачущую девочку.

Горе ее ослепило меня. Если, Господи, я пренебрегу им, я пренебрегу одной из частичек мира, и творение мое не будет завершено. Я не отворачиваюсь от великих целей, но не хочу, чтобы плакала и малышка. Только тогда мир будет в порядке. Маленькая девочка - тоже крупица Вселенной ${ }^{43}$.

$* * *$

Такая гуманная концепция социального построения еще никогда не была воплощена на нашей Земле в пределах доступной человечеству истории. Хроники и летописи повествуют о великих правителях, проливавших реки

38 Напутствие Вождю, с. 144.

39 А. Сент-Экзюпери, ор. cit., том 2, с. 62.

40 Ibid., c. 61.

41 Ibid.

42 Ibid.

43 Ibid., c. 62-63. 
крови во имя благоденствия своего государства. Наш великий соотечественник Ф.М. Достоевский устами одного из своих героев говорил о невозможности построения здания человеческого счастья на слезинке замученного ребенка и потому - о принципиальной невозможности его существования на Земле...

Но, возможно, сокровенная мечта о боговдохновенном Правителе - Иерархе, оформленная в начале XX века в текстах двух удивительных произведений, в отдаленном будущем воплотиться в социальной реальности. Огненная мощь духа Вождя, устремленного к Высшему, сакральное значение Культуры в создаваемом по законам высшей справедливости государстве помогут человечеству разрешить доселе неразрешимое противоречие между благополучием общества в целом и благополучием каждого конкретного человека. Ведь будущий ход мировой истории творится не в кабинетах современных политиков. Вехи грядущей эволюции складываются надземно, благодаря высокому творчеству человеческой мысли, созвучному Божественной Красоте.

\section{Библиография}

Бердяев Н.А., Смысл истории, Мысль, М. 1990.

Губман Б., Маленький Прини над ичитаделью духа [в:] А. Сент-Экзюпери, Сочинения, в 2 т. - Т. 2, Цитадель-Согласие, М. 1994.

Листы сада М. Зов., МЦР, М. 2003.

Напутствие Вождю, Рига 1937.

Сент-Экзюпери А., Сочинения, в 2 т. - Т. 2. Цитадель-Согласие, М. 1994. Шапошникова Л.В., Град Светлый, М. 1998. 